en vierde groep ontvingen de instructie middels een animatie met tekst respectievelijk na afloop en voorafgaande aan de tekst. Dezelfde constructie vond plaats voor de vijfde en zesde groep waarbij in plaats van tekst mondelinge uitleg werd gegeven. Uit de resultaten bleek dat de informatie beter wordt onthouden wanneer zowel het auditief als het visuele geheugen wordt aangesproken dan wanneer alleen visuele informatie wordt aangeboden.

Multimediale instructie dient derhalve te bestaan uit visuele informatie in de vorm van plaatjes of animaties (geïntegreerd) met mondelinge uitleg.

M.C.M. Ehren, AMC-UvA, Amsterdam.

\section{Docenten vergeten bij Marshallhulp}

Levinson W, Rubenstein A Mission critical - integrating clinician-educators into academic medical centers. N Engl I Med 1 999,341:840-3.

Gedurende de laatste drie decennia is in de Verenigde Staten in de academische medische centra de aandacht voor onderzoek sterk toegenomen. Om ook onderwijstaken te kunnen blijven uitvoeren worden steeds meer clinici-docenten aangesteld. De auteurs vragen zich af in hoeverre deze clinici-docenten onderdeel worden van de - zoals ze dat noemen - 'fabriek van het academische ziekenhuis' en of ze kritisch staan tegenover de 'missie van dat ziekenhuis' en welke status en carrièremogelijkheden ze hebben ten opzichte van hun collega-onderzoekers.
'Wetenschappers' kunnen het helemaal maken. Patiëntenzorg doen ze echter weinig, meestal niet meer dan een dagdeel per week. De clinici-docenten daarentegen, verrichten veel werk in de polikliniek en koppelen dit aan de begeleiding van studenten en arts-assistenten. Onderzoekstaken hebben clinici-docenten veelal niet. Dikwijls worden ze gezien als excellente artsen en docenten en het zou dan ook logisch zijn als instellingen clinici-docenten zouden erkennen als minstens zo belangrijk als wetenschappers voor het bereiken van de doelstellingen van de instelling. Maar is dat wel zo? Een groot aantal gerenommeerde opleidingsinstituten hebben speciale carrièretrajecten voor docenten gemaakt, maar deze leiden veelal niet tot vaste aanstellingen, terwijl dat voor onderzoekers wel het geval is. Uitblinken in onderwijs is in naam wel een vereiste om 'associate' of 'full professor' te worden, maar in werkelijkheid onvoldoende. Ook voor docenten is het aantal publicaties doorslaggevend. Verder zijn de clinici-docenten vaak generalisten, hetgeen met zich meebrengt dat ze niet gevraagd worden voor bijdragen aan nascholingen en congressen, hetgeen weer een negatief effect heeft op de carrièreontwikkeling.

De auteurs concluderen dat er voor clinicidocenten weliswaar op papier carrièremogelijkheden zijn, maar dat deze er in werkelijkheid niet zijn omdat hun werk niet op waarde wordt geschat. Ze bevelen aan om bij de aanstelling van docenten niet langer het criterium 'regionale reputatie' en lengte van de publicatielijst te hanteren. In plaats daarvan moeten instellingen zelf bepalen welke waarde docenten voor de opleiding (kunnen) hebben en hen daarop ook daadwerkelijk belonen.

J.R.E. Haalboom, Utrecht. 